\title{
الحرف العمانية التقليدية بين التقتية والتصميم "دراسة تحليلية"
}

\section{Traditional Omani Crafts between Technical and Design "Analytical Study}

أ.م.د/إسلام محمد السبد هيبة

أستاذ التصميم المساعد بقسم التربية الفنية

كلية التربية النوعية جامعة المنوفية

\section{مقدمة البحث}

الحضارة هي كل ما يميز أمة عن أمة أخرى، من حيث العادات والتقاليد، اسلوب المعيشة والملبس، والتمسك بالقيم والاخـلاق، وهى عبارة عن نظام اجتماعي يعين الانسان على زيادة انتاجه النقافي، وهى ترتكز على شيئين هامين، العلم والفن.

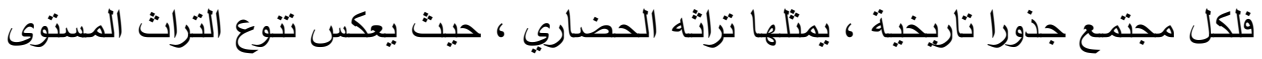

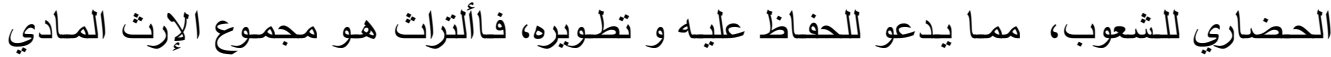

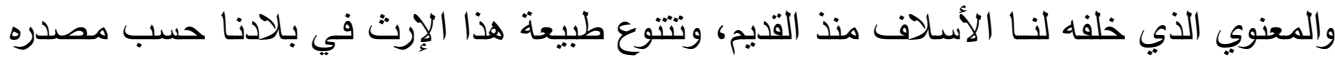

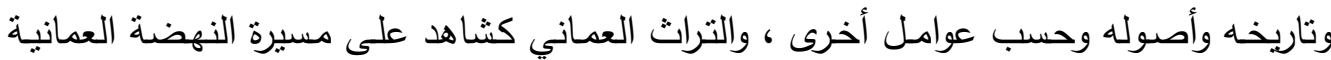

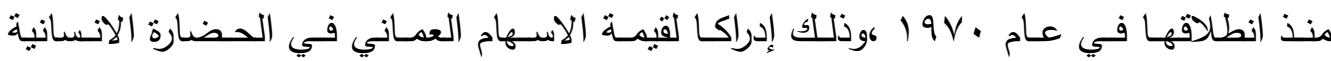

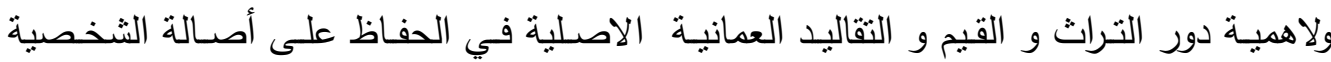

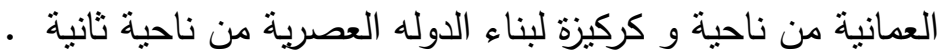

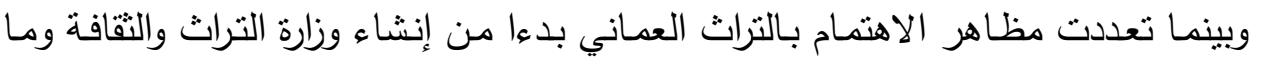

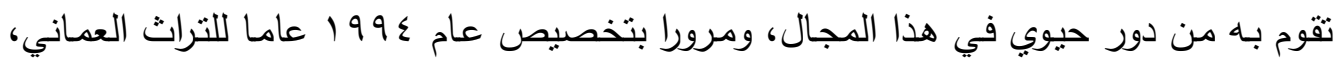

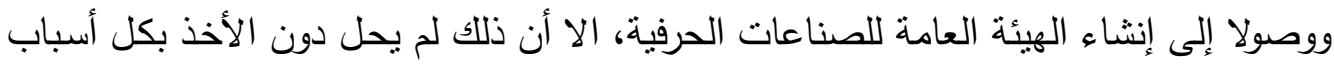

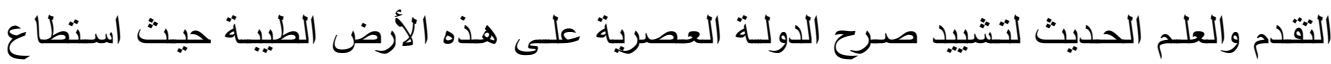
المجتمع العماني أن يجمع بين الطيب من تقاليده والطيب من واقع حاضره.

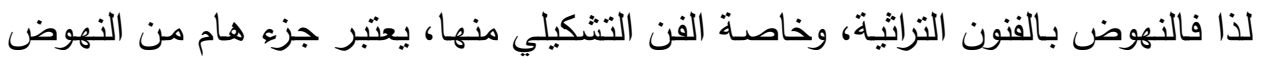

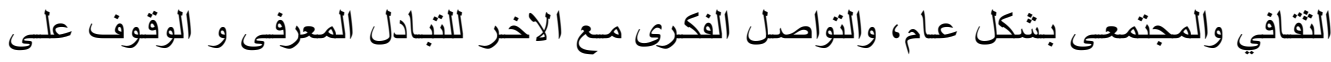

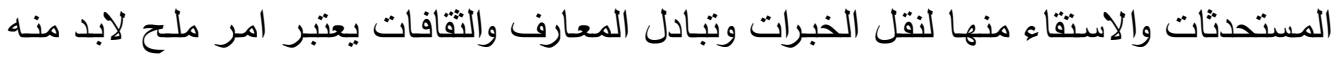
ولكن يجب ان يغلف كل ذللك فى اطار الحفاظ على القومية الوطنية من خلال دراسة التاريخ

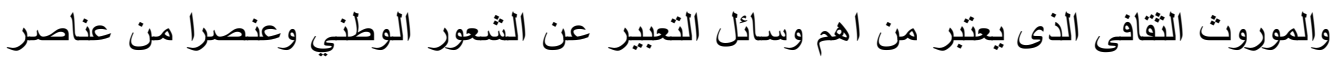

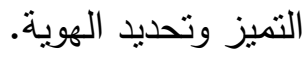


والخامـة هي وسيلة من وسائل التعبير أو الإنتاج الفني الوظيفي، فهي تكتسب المعاني

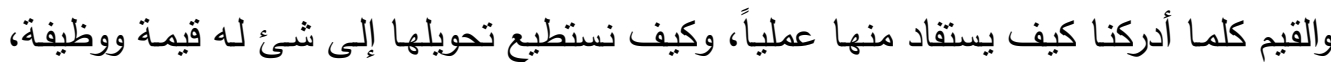

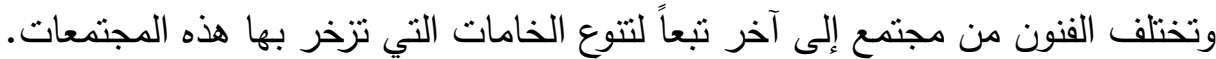

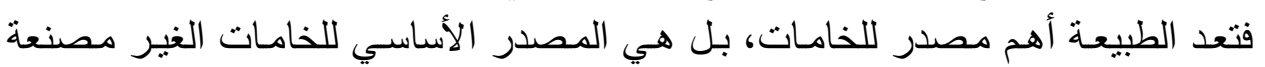

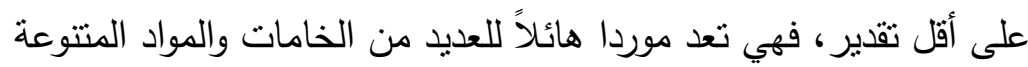

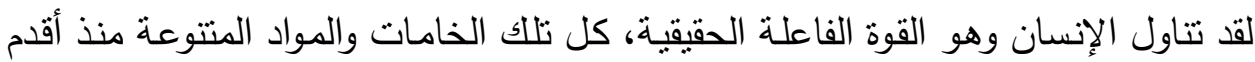

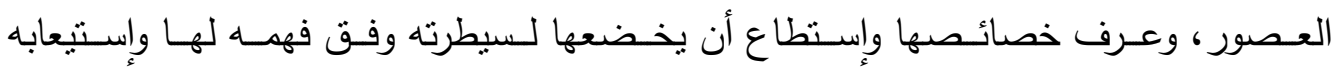
لإمكانياتها لتحقيق أقصى فائدة مدكنة تخدم بقائه.

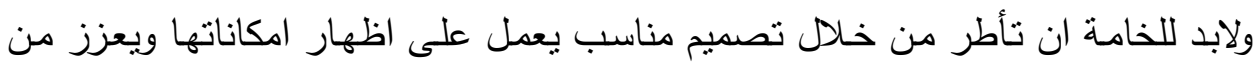

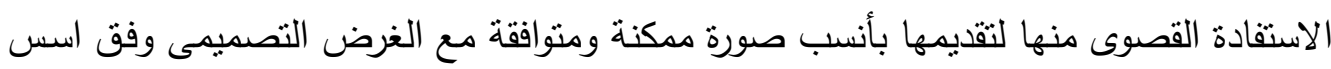
ومعايير التصمميم الفنية

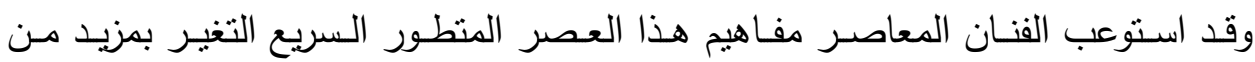

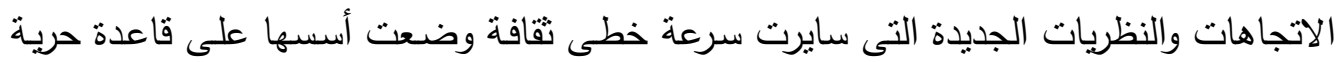

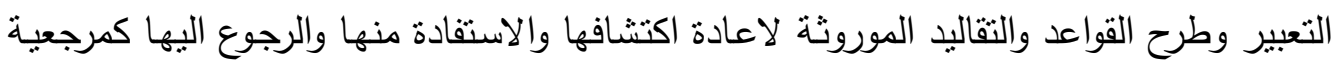

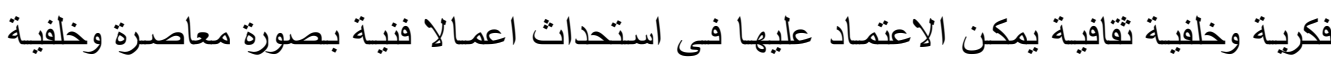
تراثية بمعنى اخر تقديم التراث بعين المعاصرة.

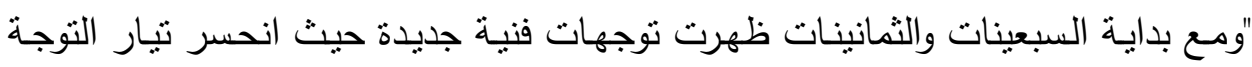

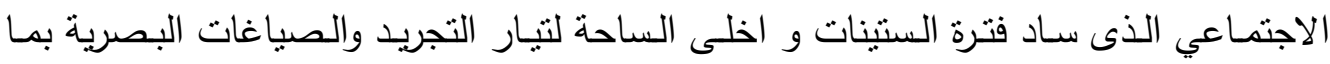

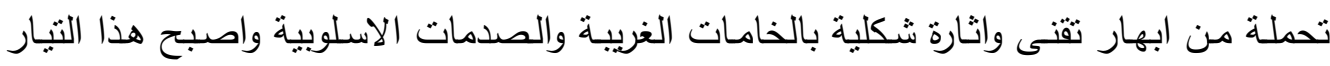

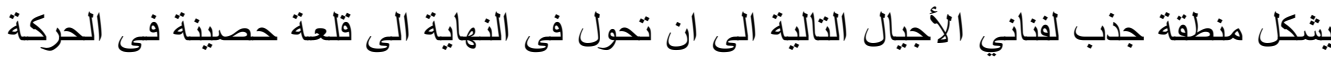

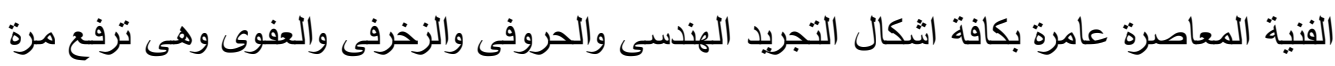

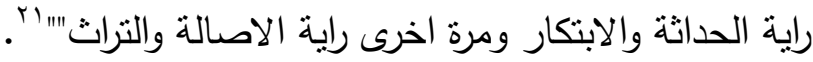

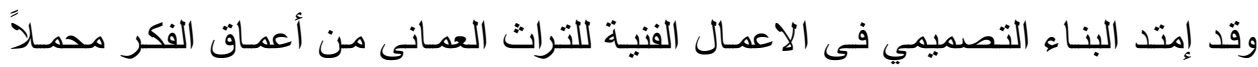

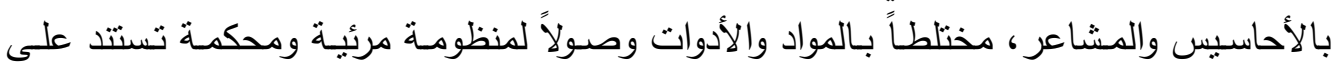

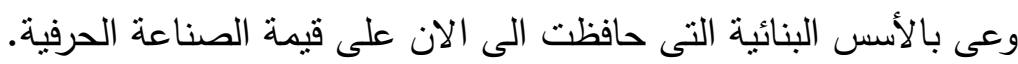

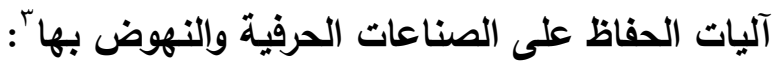

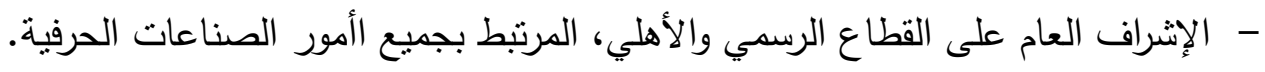
- صياغة القوانين المرتبطة بمجالات الصناعات الحرفية.

$$
\text { - }
$$

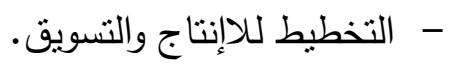


- - التخطيط التعليمي لدراسات الصناعات الحرفية. - التخطيط النقافي في مجال الإنتاج الحرفي. - التخطيط الإعلامي لنسر الوعي بأهية الإنتاجية السناعات الحرفية.

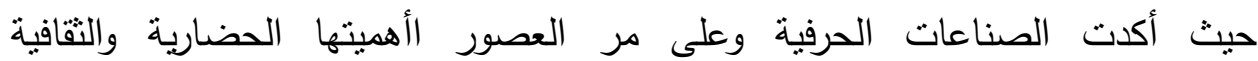
والاقتصادية لحياة الثعوب ومتطلباتها المعيشية . وسلطنة عمان تعتبر من الدول الرائدة في مجال الصناعات الحرفية منذ عهد بعيد، حيث لعبت في المجتمع المحلي الذي تتوع في صنع العديد من الحرف وتفنن في هندستها واخراجها بشكل مبدع وحس مرهف. فقد لعبت البيئة المحيطة بالانسان الحرفى دورا مماثلا لا تقل أهمية فتتكلت من هذه

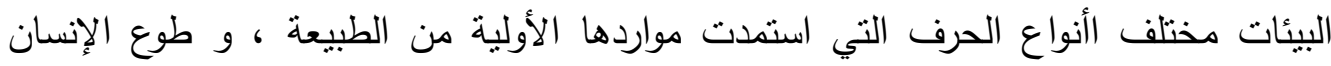

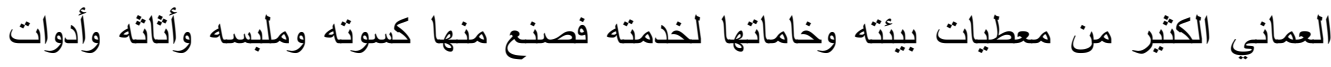

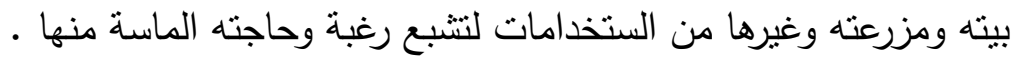

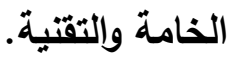

التقنية لها دور هام وأساسي في أي عمل فني تشكيلي، لأنها تمثل خبرة الفنان وقدرته

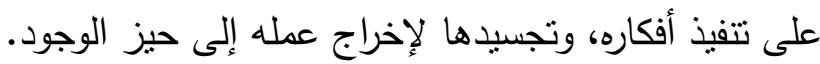
وقد ظهر دور التقنية في الفن الحديث مع التقدم العلمي والتكنولوجي الصناعي في مجال التهال

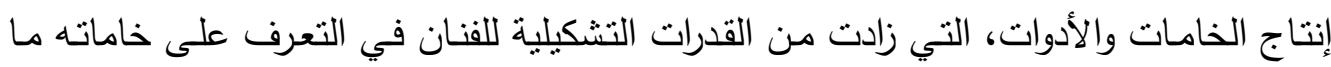

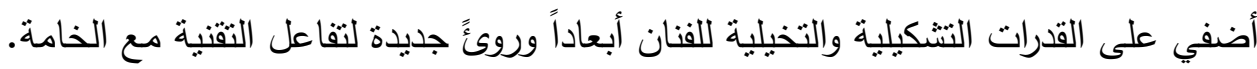

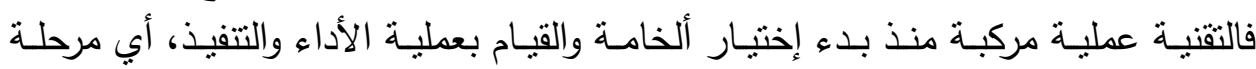

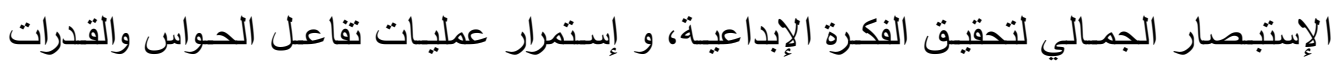

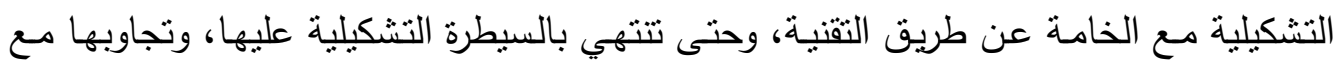
الفكره التخيلية. مفهوم التقتيات:

هى تلك الحالة الادائية المميزة التى تشمل القدرة على الإختراع، وإن وجدت في أعمال

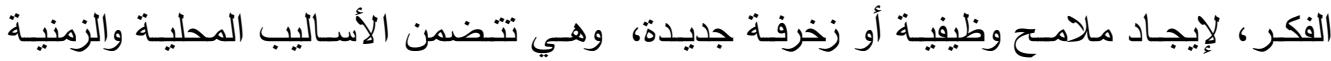

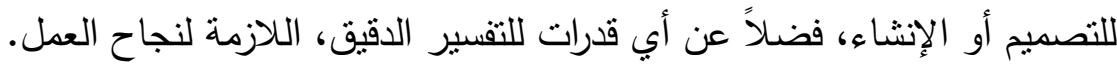

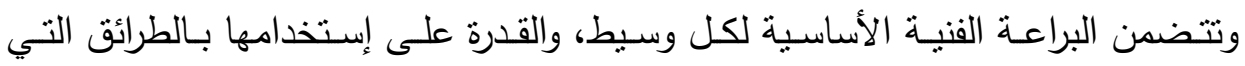

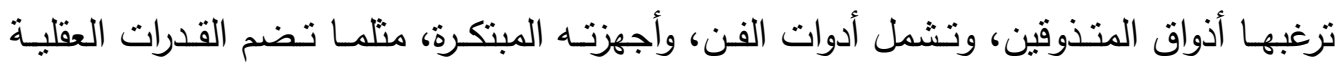

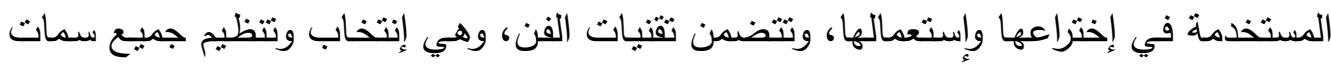

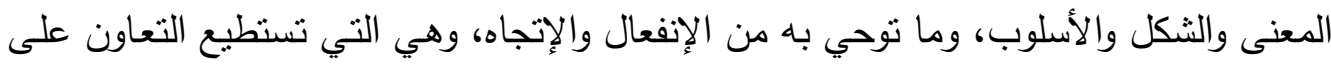
إنتاج أثز سيكولوجي مرغوب. 
ومن اهم الحرف العمانيـة التى تميزت بتقنيـة غايـة فى الدقة والاتقان، صناعة الخنجر

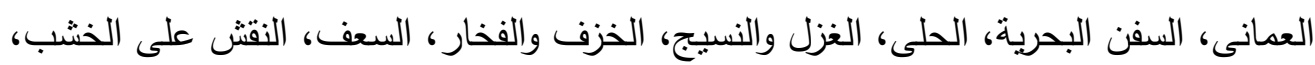

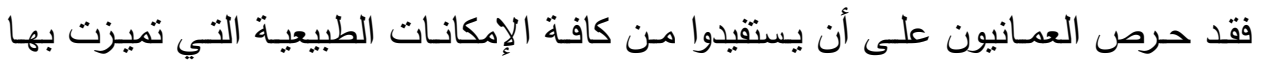

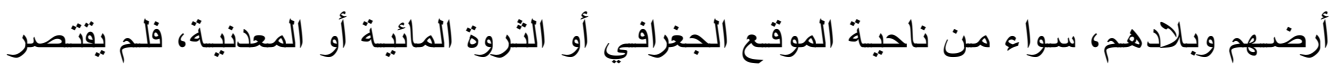

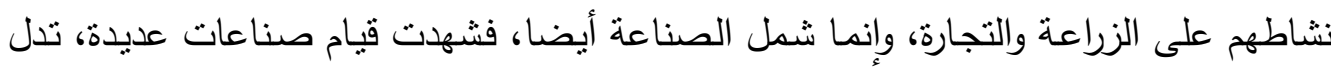

كلها على مهارة وقدره على تسخير موارد الطييعة والاستفادة منها ومن هذه الحرف على على سبيل المثال:-

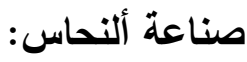
وتشتهر المصنوعات النحاسية العمانيـة بدقة صناعتها وجمال أثكالها وتتاسق أجزآئها،

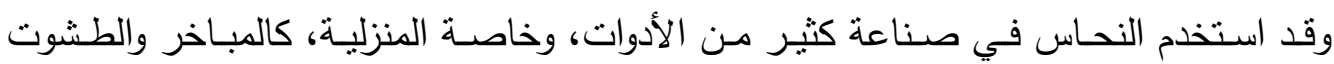
والأباريق والدلات (أباريق القهوة) وغيرها.

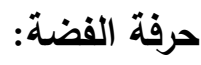

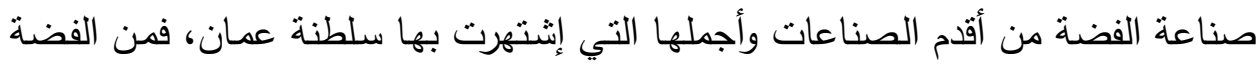

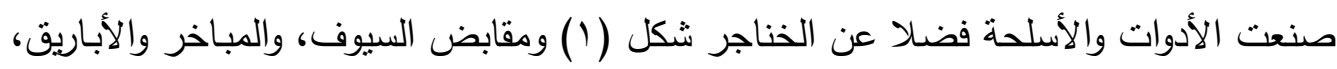

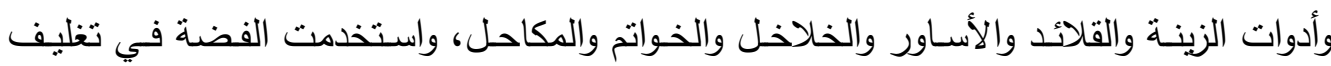

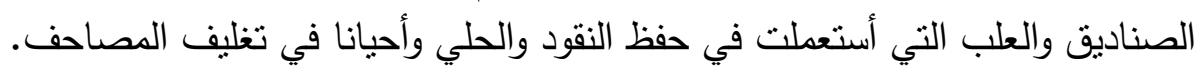

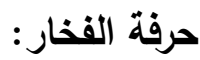

صناعة الفخار كان لها شأن كبير في عمان منذ أقدم العصور ، وهنـاك نمـاذج أواني

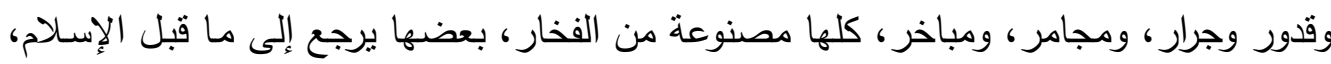
والبعض الآخر يرجع إلى العصور ومجئ ومباخل الإسلامية.

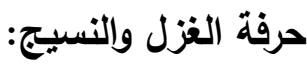

قامت صناعة الغزل والنسيج على أساس الإنتاج الحيواني والزراعي، حيث إنتهرت عمان

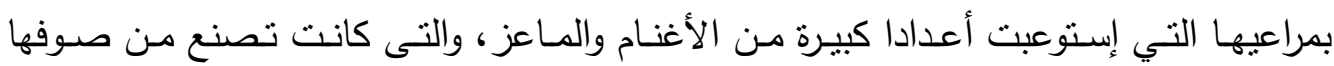

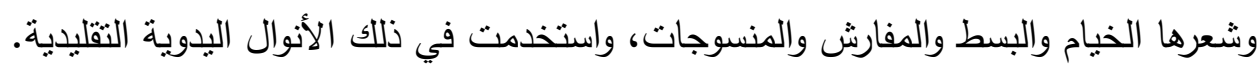

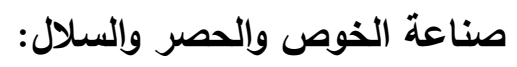

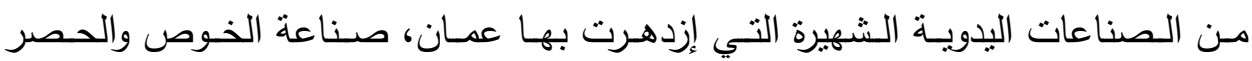

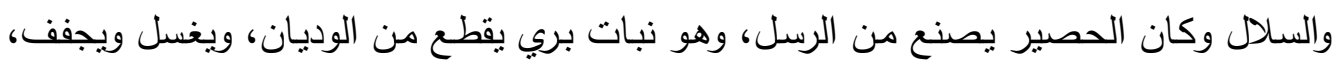

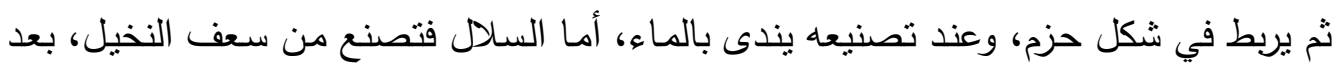

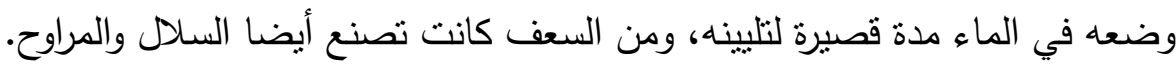
التصميم فى الحرف العمانية:

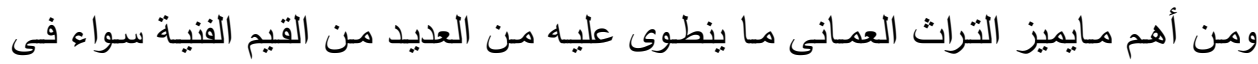

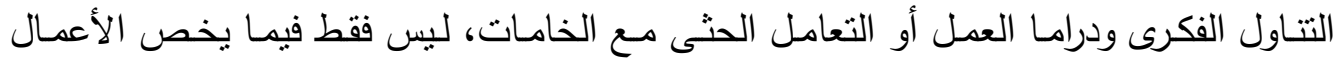
المسطحة وما ميزها من منطلقات نشكيلية مثل: 


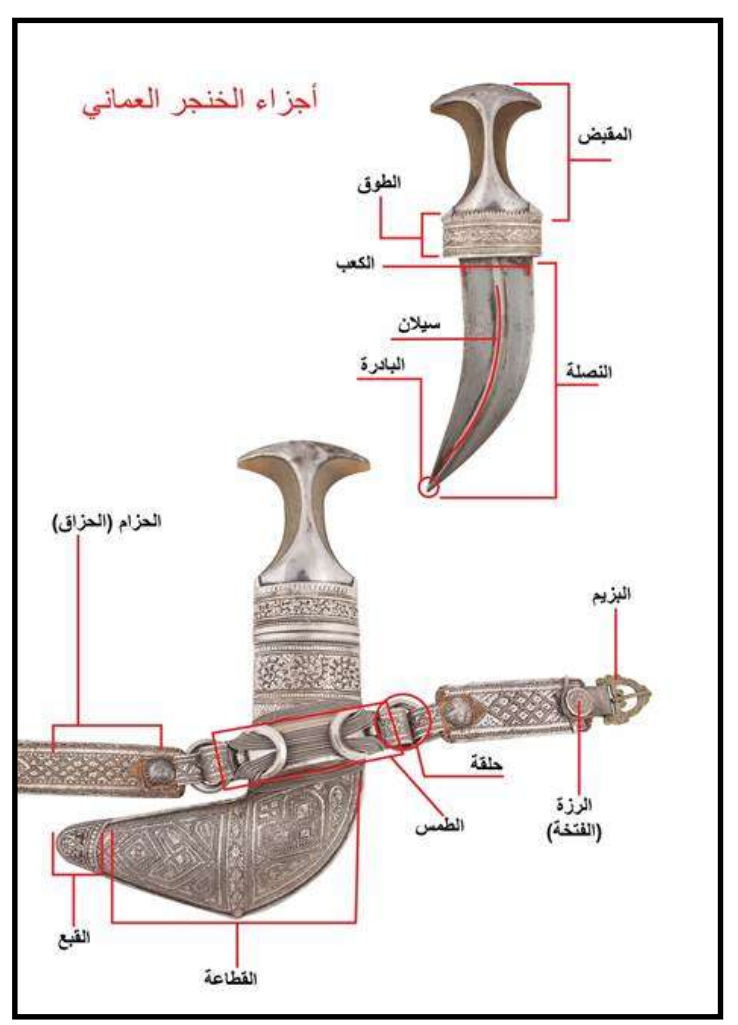

شكل ( (1) اجز اء الخنجر العمانى ومكوناته

$$
\mid
$$

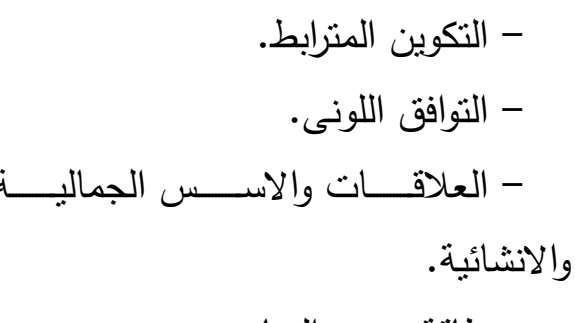$$
\text { - طاقة وضع العناصر • }
$$$$
\text { - الصياغة الثكلية والخطية. }
$$

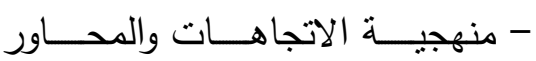

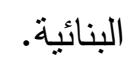

بـل امتد ليشمل الاعمـال الفنيـة

ثلاثبـة الابعـاد حيـث تبـدوا كمـا لوكانــ

لوحـة زخرفيـة فتنوعـت الخامـات والاتثار

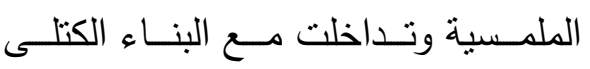

المتـزن فــى علاقـات متتاغمــة شــــليا

وتشكيليا شكل، والتى تميزت بما يلي:

- الثراء الملمسى. -

- البناء التصميمى. - - المعي.

$$
\text { - القيم الحركية. }
$$

- العلاقات الكتلية.

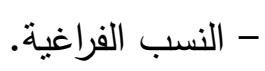

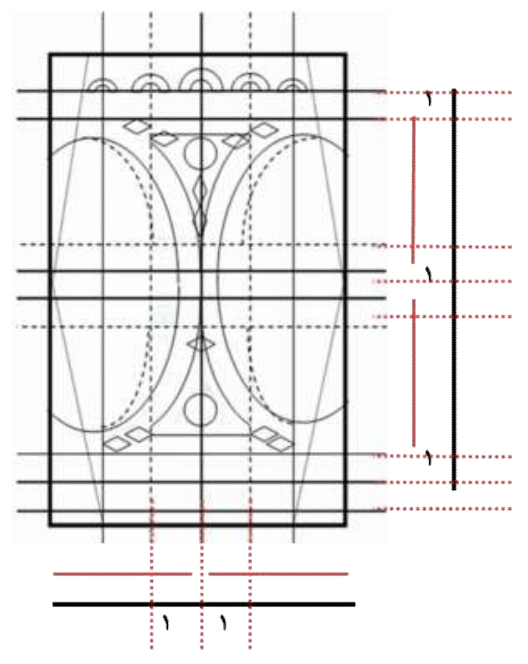

وفيما يلي يقدم الباحث تحليلات خطية لبعض

العناصر من التراث العمانى والتى يتضح بها التقنين الثكلى والبناء المتوازن والقيم الملمسية والصياغات الثكلية التى اعتمدت على منهجية رياضية وخلفية عقلية. 


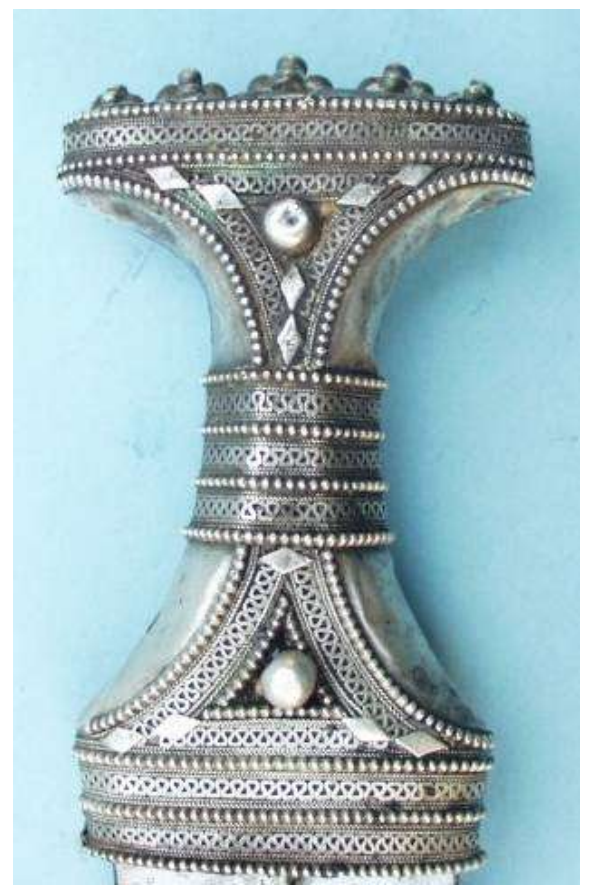

شكل (Y) نموذج أ ... التحليل الخطى للبناء

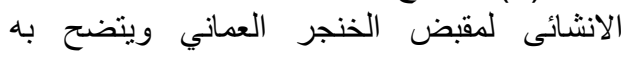
الضبطية الثكلية والتناسبات الرياضية

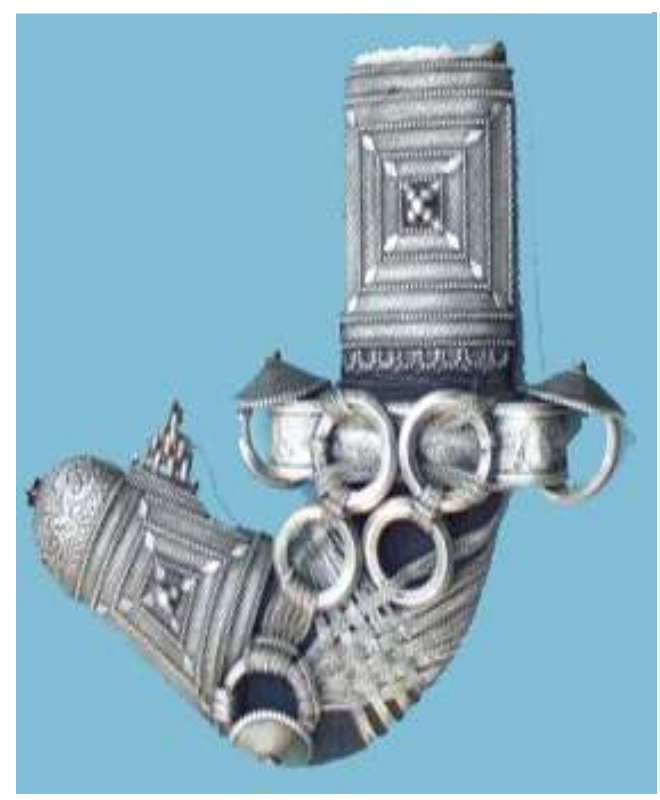

\section{الخنجر العمانى:}

من المالمح العمانية التي لا يزال المجتمع محافظا عليها، ويعتبر لبسها من مظاهر أناقة الرجل العماني، حيث يندر مشاهدة رجل عماني، ولا سيما الوجهاء والأعيان لا يلبس خنجراً في حفل رسمي أو في المناسبات الوطنية والخاصة كعقد القران والزفاف والتكريم وغيرها، وقد كان

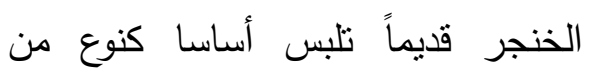
السلاح للدفاع عن النفس، وأصبحت الآن من إكسسوارات الأناقة ولوازم الوجاهة التي لا يستغنى عنها، وهي من الهدايا الثينة التي يقدمها العماني لضيف أو عزيز لديه تصنع الخنجر من الفضة الخالصة، وبستغرق نقشها فترة طويلة قد تصل إلى شهر كامل بحسب نوعها شكل

وهنالك طريقتان لنقش الخنجر هما:

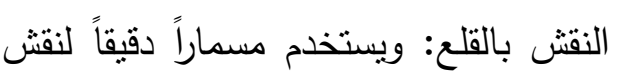
الصفيحة الفضية حيث يتطلب ذلك صبراً ومهارة لتظهر النقوش كعمل فني متقن. نقش التكاسير: وهو الطريقة الثانية وفيها يستخدم الصائغ خيوط الفضة في تزبين الخنجر وهذه من الأمور المستحدثة في صياغة الخنجر صن يتضح فى هذا التحليل البنائى للمحاور 
العدد الثامن اكتوير 17 • r (الجزء الاول)

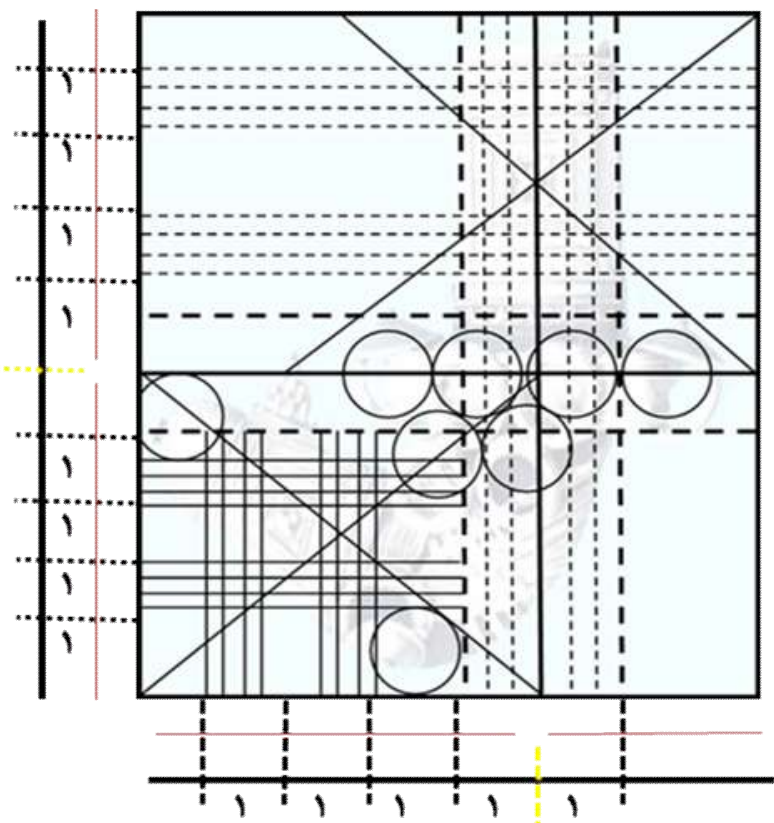

شكل (r) نموزج ب .. جراب الخنجر العمانى وما يتميز به من انشائية هندسية وقيم بنائية مميزة اضفت علية نوع من الضبطية الشكلية والعلاقات التتاسبية

\section{المجلة العلمية لكلية التربية النوعية}

الرئيسية الخنجر العمـانى مـايتميز بـهـ مـن ضـبطية شكلية وتتاسـبات رياضية فى العلاقات الجزئية بين مكوناته فالمحاور الرأسية والافقيـة جائـت في تعادليـة منزنـة تتاغمـت معهـا الخطـوط العضوبة والـدوائر فى ايقاع اضـفى نـوع من الحيوبـة والتتوع.

ايضا فيما يلي تحليل لبعض الزخارف السطحية لعناصر من التراث العمانى مثل الارابيسك والزخارف النخيلية والحلى وحاوبة الكحل والابواب والثبابيك شكل $\left(r_{6} \varepsilon_{60} 0.76 v\right)$ 
العدد الثامن اكتوير 1 ا ـ r (الجزء الاول)

المجلة العلمية لكلية التربية النوعية
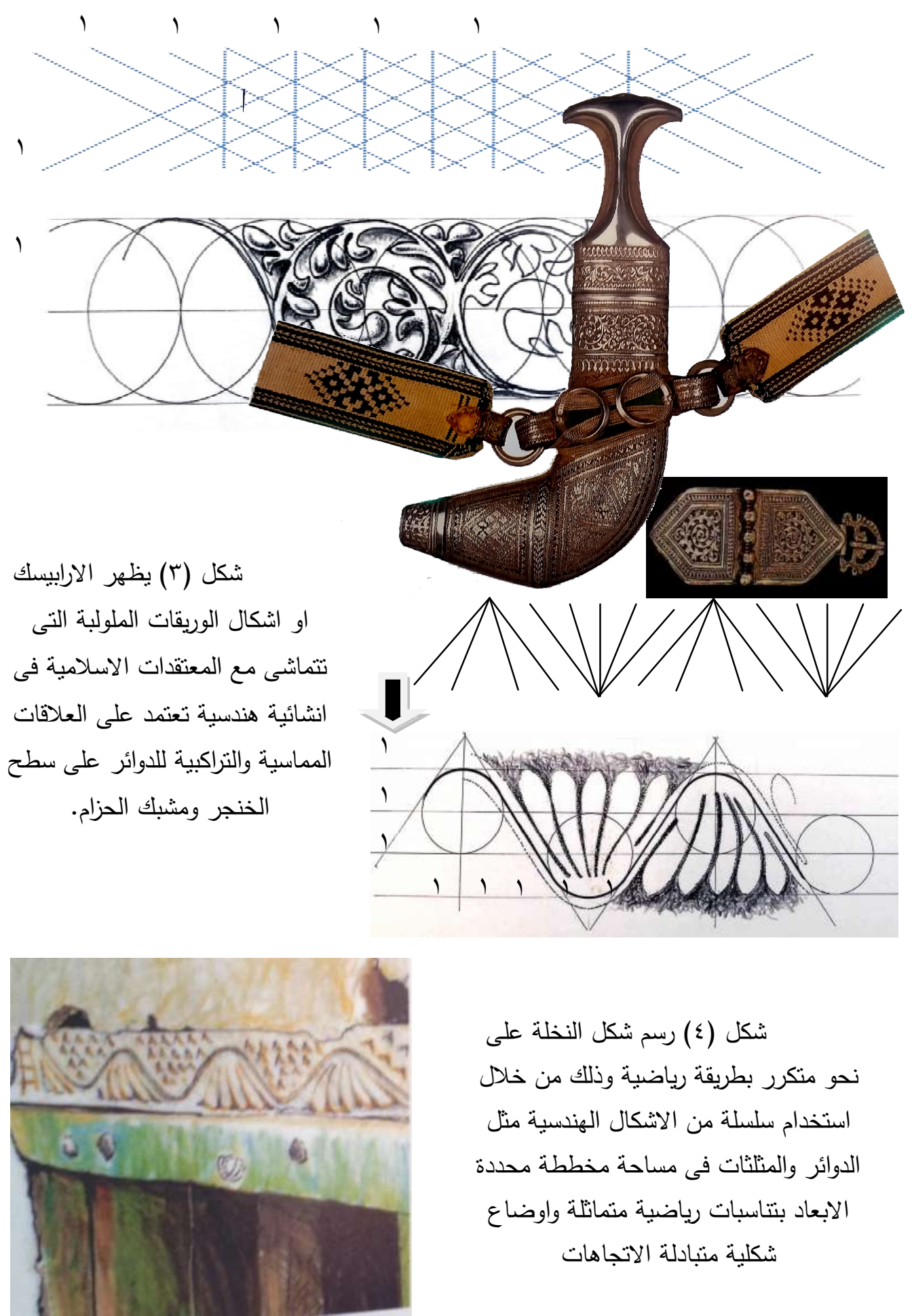

شكل (ع) رسم شكل النخلة على

نحو متكرر بطريقة رياضية وذلك من خلال

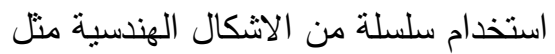

الدوائر والمنلثات فى مساحة مخططة محددة

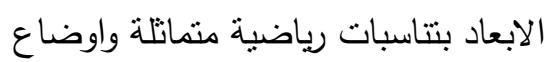

شكلية متبادلة الاتجاهات 


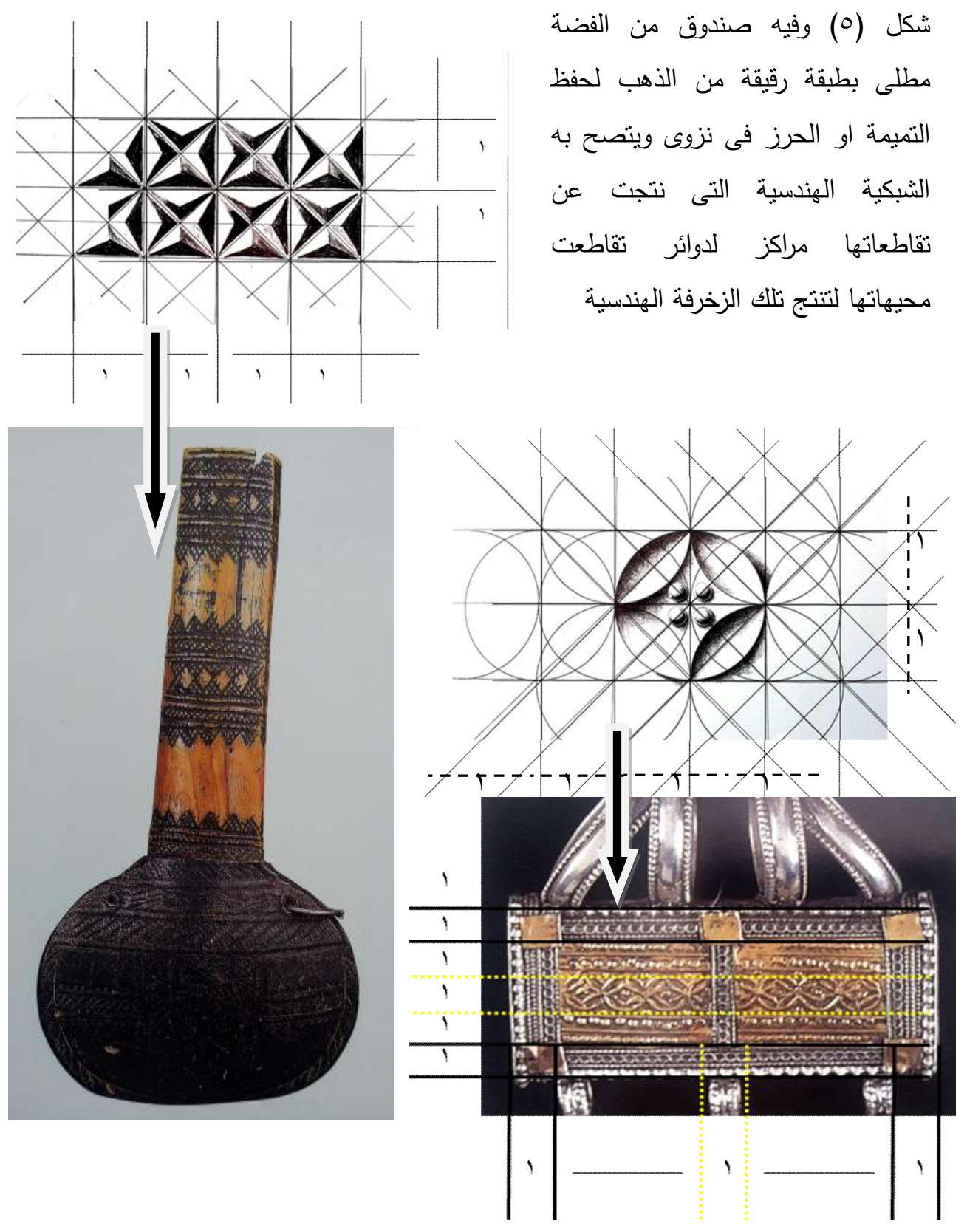

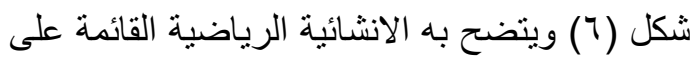

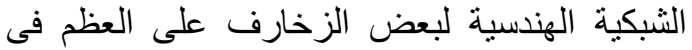

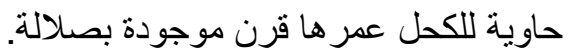




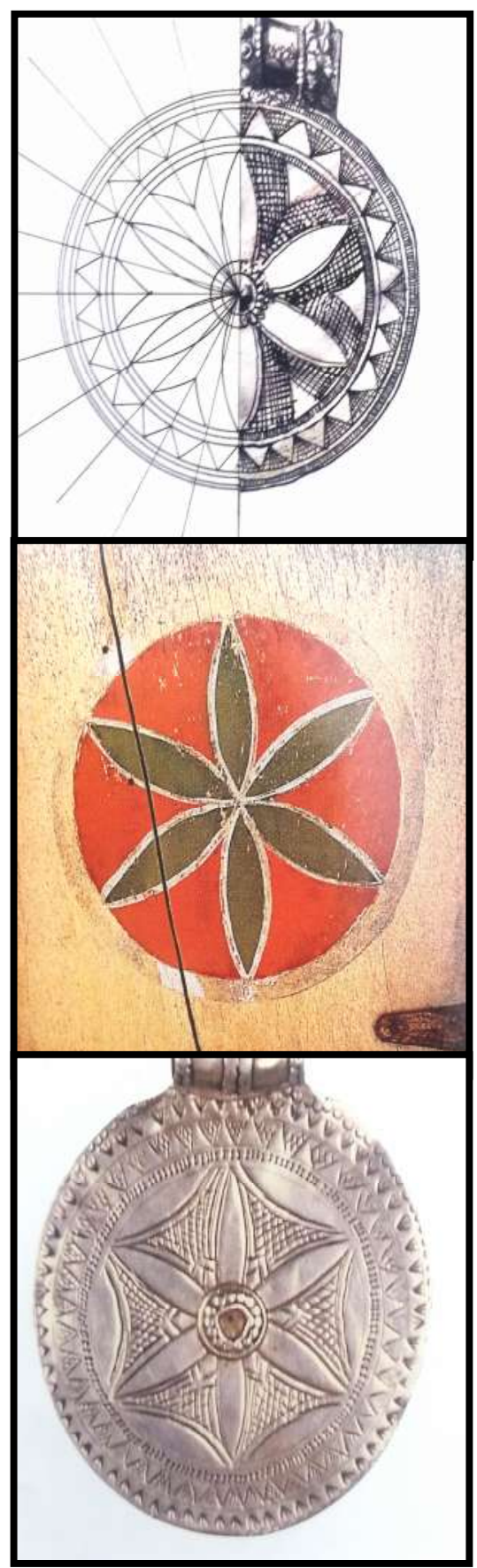

وبرتبط التطور التمـوي في السلطنة ارتباطا وثيقا بمفـــاهيم المـــوروث الــشعبي والتـــراث والقـــيم الاجتماعيـة، واسـتطـاع أفـراد المجتمــع العدـاني المحافظـة على كثيـر مـن الخصوصيات الثقافيـة والإرث الحضاري.

ورغم أن الصناعات التقليديـة العمانيـة كانـت في الماضـي صـناعات حيوبـة تشكل قوام الاقتصاد، حيث كان للظروف المعيشية دورا كبيرا في إتقان العمـانيون للصناعات الحرفيـة، ورغم شـح المـوارد وظـروف الطبيعـة القاسـية فقـد اسـتطاع الإنسـان العماني أن يستخل المصادر المتوفرة حوله سـواء في الصحراء أم في الريـف. واسـتطاع أن ينتج

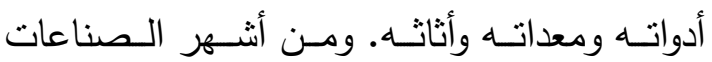
الحرفية التي لا بزال العمانيون متمسكون بها والتي تشكل موردا لرزقهم: الفضبات والفخار والسعفيات والحـدادة والنجـارة والجلـود والعطـور والنسيج. مـن جانب آخر ، جاء التغيير التكنولوجي منزامنا مع ما تشهده السلطنة من تتمبة شـاملة وتطوبر في شتى مبـادين الحيـاة، وأدي بـدورة إلـى تغيـر في الحيـاة الاقتصادية والاجتماعية في السلطنة، مؤثرا أيضا على كثيـر مـن الـصناعات التقليديـة والعـادات والتقاليد المرتبطة بها.

شكل (V) يوضح التكوين البنائى الذى يعتمد

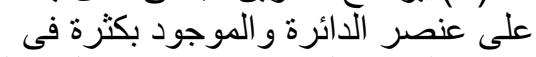
الزخارف العمانية لما بتميز به من كمال شكلى فئى فئ 
يتضح من التحليلات الخطية للصيغ الثكلية والقيم البنائية للنمازج السابقة من عناصر

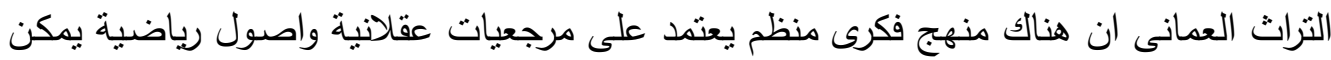

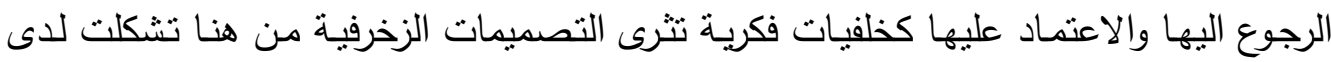

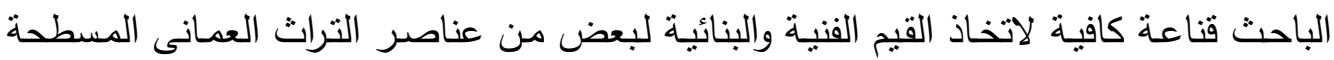

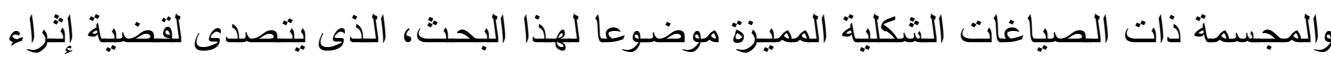

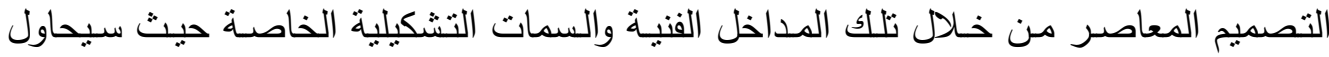
الباحث فى هذا الدراسة كثف وتحليل القيم الفنية والجمالية والنظم البنائية والانثائية التى ميزت

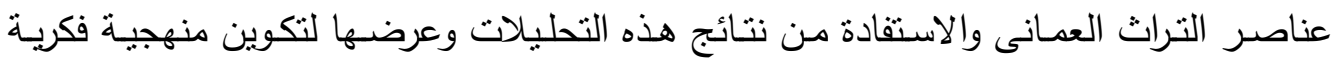

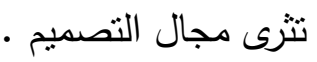
وفى خاتمة هذه المقدمة يؤكد الباحث على مدى أهمية وثراء التراث العماني بما يتضمنه

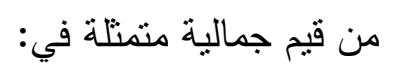

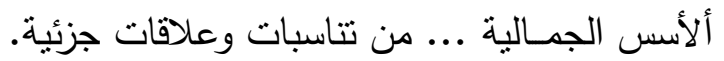
.... توازن محوري ومركزي ومحيطي. تئ. (... وحدة النتكيل والمضمون. ... الإيقاعات والتكرارات الثكلية والخطية. الأسس البنــائية ... سواء لعنصر التشكيل. .... أو الوحدات الزخرفية (هندسية وعضوية).

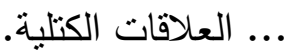
. . الفراغات البينية والمحيطية. الأسس الإنشائية ... وتتمثل في ثراء الصياغات السطحية.

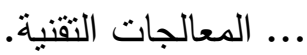

مما سبق ... يصبح التراث العمانى منهل خصب ومصدر ثرى ومرجعية فكرية يستطيع

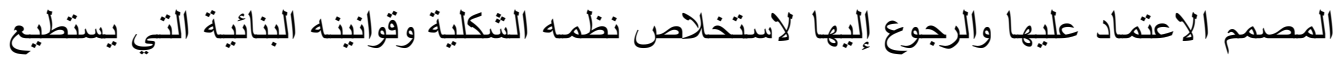
من خلالها استحداث تصميمات عصرية ذات أصول ومدلولات فكرية أساسها التراث الفني العماني. ثانيا: مشكلة البحث:

لكل أمسة تراث تعتز بـه وترجع إليهه ويميزها، فهو الذي يشكل طابعها الثقافي وتكوينها

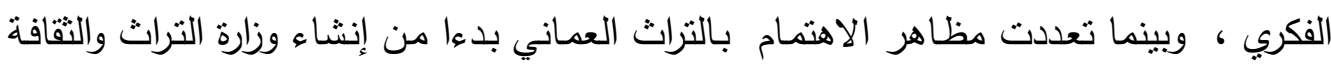

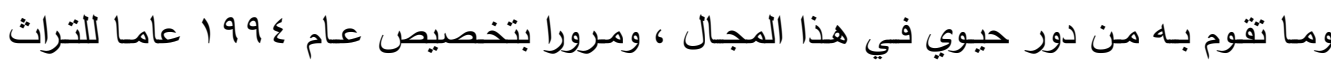

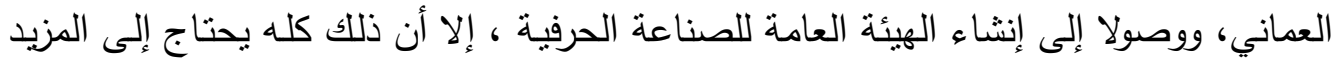

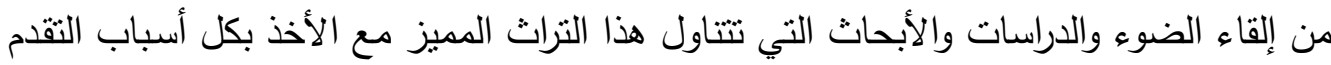

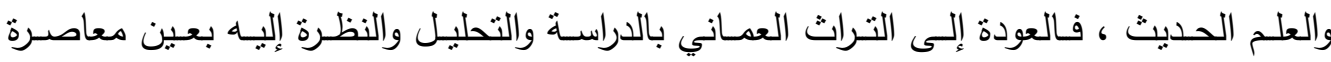


للاستفادة من معطيات عناصره الجمالية وأسسه البنائية في استحداث فكر تشكيلي يجمع بين

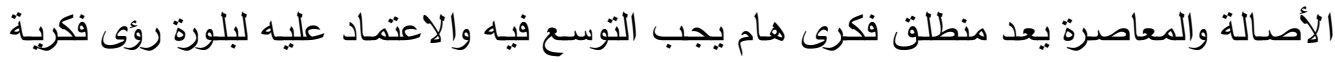
جديدة لإحياء ذلك الموروث الثقافي في هيئة معاصرة من خلال الممارسات الفنية والتجارب الحديثة :وقد تكونت هذه الرؤية لدى الباحث من خلاء عدة ملاحظات:

ا -قلة الدراسات والبحوث المتخصصة التي تتاولت التراث العمانى رغم ثرائه الفنى والجمالى. r-تتحدد مشكلة البحث في دراسة وتحليل واستخراج القيم الجمالية لنماذج من التراث العمانى،

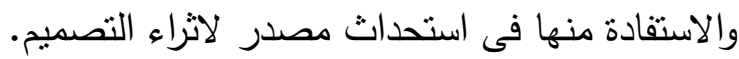
وفى ضوء ما سبق يطرح البحث التساؤلات التالية: -

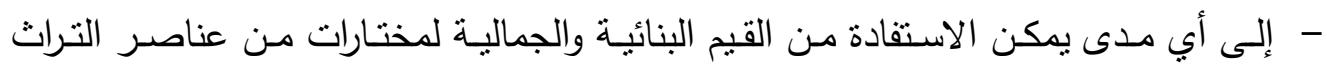

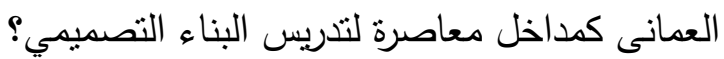
- كيف يمكن إثراء مجال التصميم من خلال دراسـة وتحليل القيم الفنيـة والجمالية لمختارات

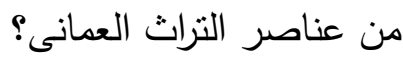
ثالثا: فرض البحث:

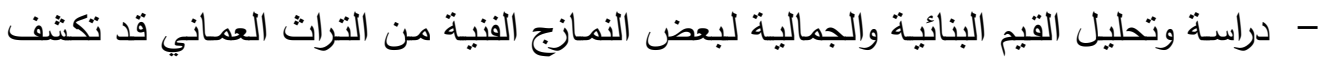
عن حلول انشائية يمكن الاعتمـاد عليها فى استحداث تكوينات تصميمية معاصـرة ثترى مجال التصميم.

$$
\text { الرعا: أهداف البحث: }
$$

- إلقاء الضوء على النظم التصميمية فى التراث العمانى متمثنلا في بعض النماذج المتميزة شكليا كمداخل جديدة نثرى مجال التصميم من خلاء كثف:

$$
\begin{aligned}
& \text { - البعد الثقافي. } \\
& \text { - القيم البنائية. } \\
& \text { - - الصيخ السطحية. } \\
& \text { - الخصائص البصرية. }
\end{aligned}
$$

- إثراء مجال التصميم من خـلال دراسـة وتحليل القيم الفنيـة والنظم البنائية لبعض مختارات من عناصر التراث العمانى.

\section{خامسا: أهمية البحث:}

- إثراء المكتبة العربية بدراسات وبحوث تعتمد في منهجها على العناصر التراثية العمانية وما

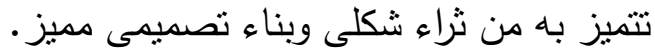

- تكمن أهميـة البحث في إيجاد مدخل فكرى جديد يعتمد على الدراسـة التحليلية للقيم الفنية والبناء التصميمي لمختارات من عناصر التراث العمانى وما تتضمنه من علاقات شكلية ولونية وقيم بنائية وجمالية، يفيد مجال التصميم. 
- تقتصر حدود البحث على تتاول بعض عناصر التراث العمانى التالية منل: - الخنجر العمانى، حاوية الكحل، الحلى، الابواب، الثبابيك.

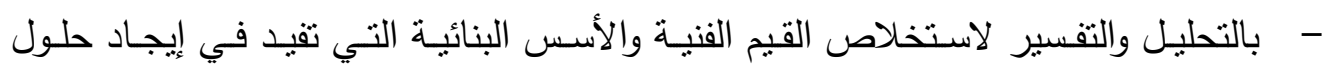
التشكيلية تثرى مجال التصميمات الزخرفية. - تتبع مصادر فكر الانسان وملهماتة من التراث والطبيعة منذ بدايتة الأولى وحتى الوقت الحالى.

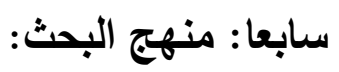
يتبع البحث المنهج الوصفي التحليلي، لتحقيق هدف البحث والإجابـة عن فرضـه على

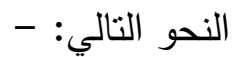
- - دراسة العامل البيئي والخلفية التقافية والمصادر المرجعية التي شكلت التراث العمانى.

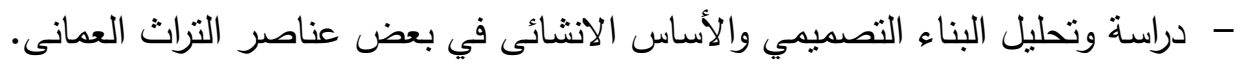

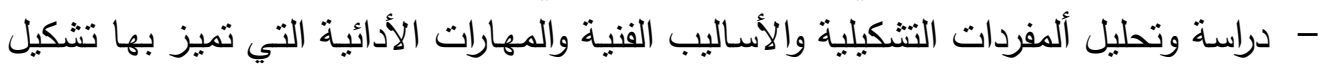
عناصر التراث العمانى. - دراسة وتحليل الصياغات الثكلية التى ميزت التراث العمانى.

$$
\text { ثامنا: مصطلحات البحث: - }
$$

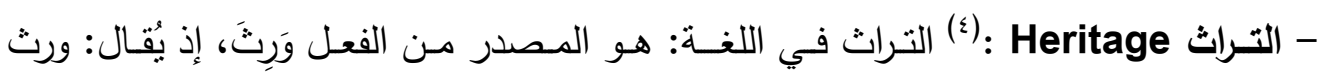

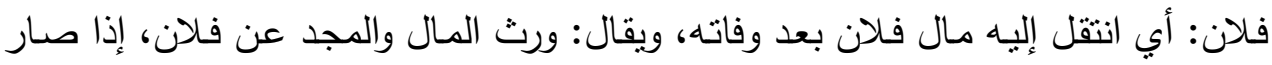
مال فلان ومجده إليه. - اليه

والتراث في الاصطلاح: لفظ يشمل الأمور المادية، والمعنوية، ويتمثل في جميع ما يبقيه الأجداد والآباء للأبناء والأحفاد. الأحلاح. أمـا التراث في معنـاه الإجرائي العام: فيشمل كل مـا خلفته الأجيال السابقة للأجيال

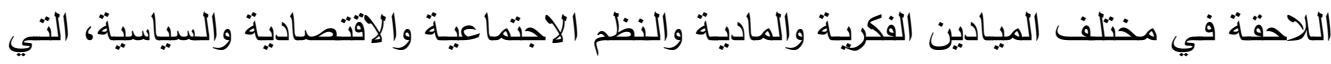

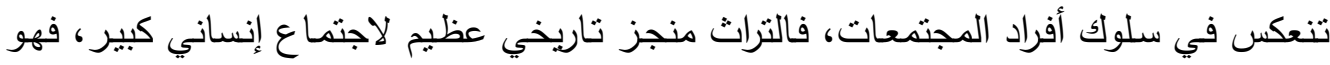

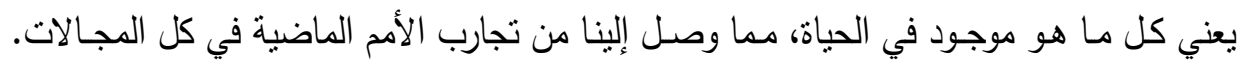

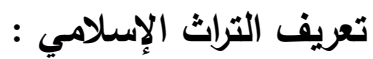

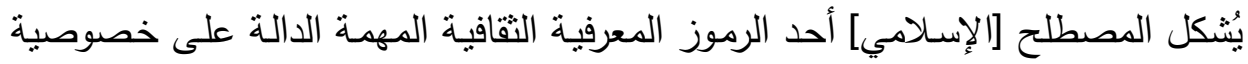

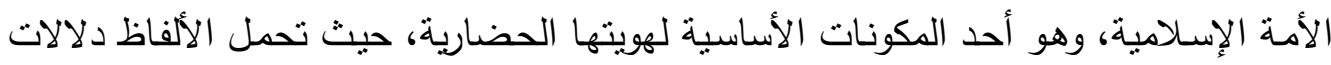

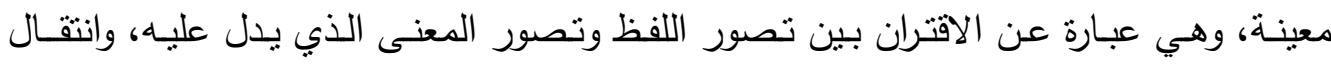

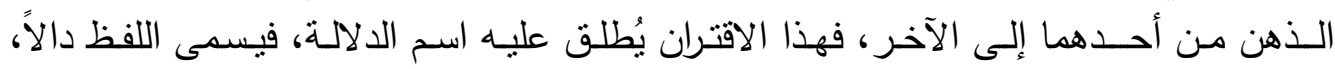
والمعنى مدلولاً. 


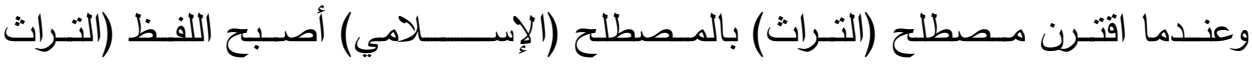

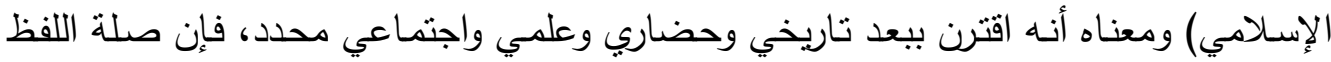

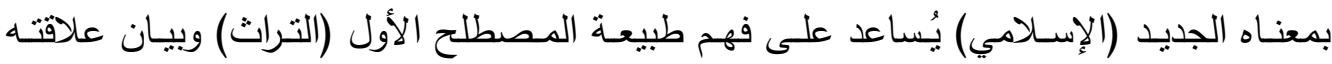
بحمولته الفكرية والمفهومية.

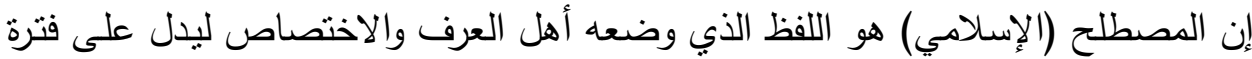
معينة من الزمن ارتبطت بظهور الإسـلام، وتشمل كل الأمور الدينيـة والفكرية والاجتمـاعية الإلية

$$
\text { والسياسية والاقتصـادية لها. }
$$

- التقتية Technique : هى أسلوب أو طريقة محددة ومميزة لصناعة العل الفنى، بما في

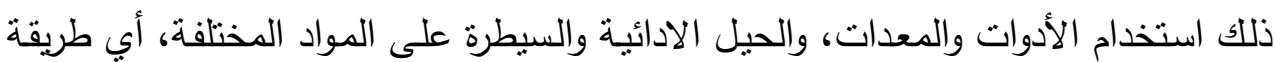

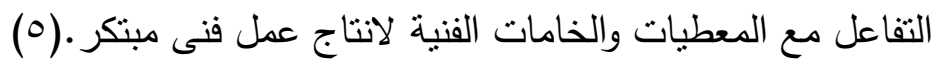

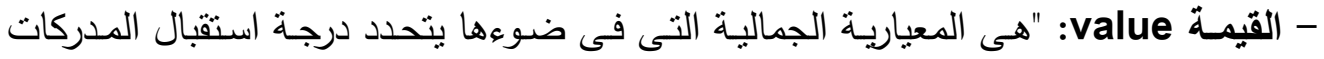

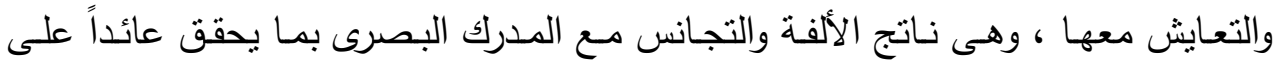

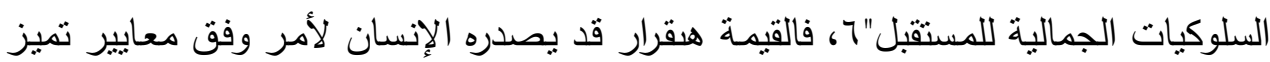

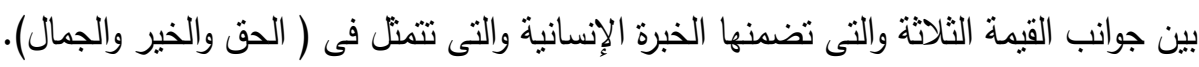

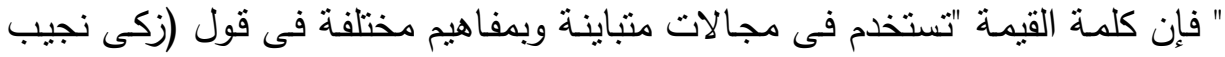

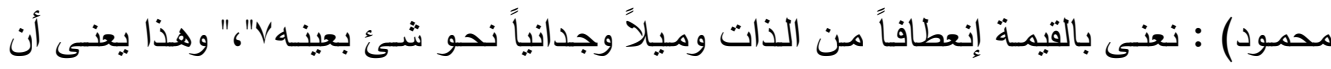

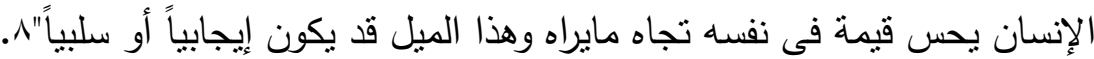

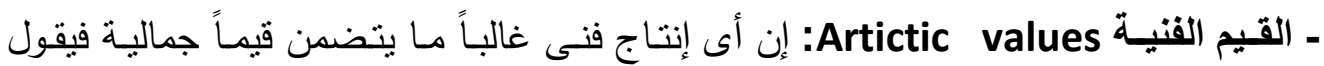

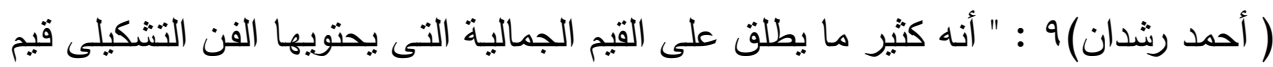

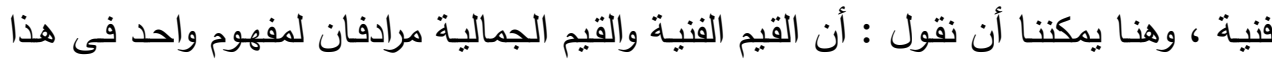

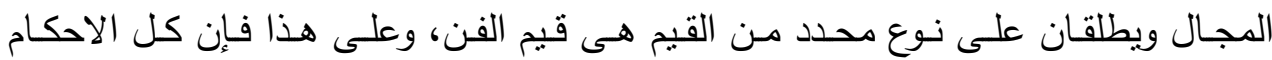
والخصائص التى تطبق على القيم الجمالية تطبق على القيم الفنبة التشكيليه" .

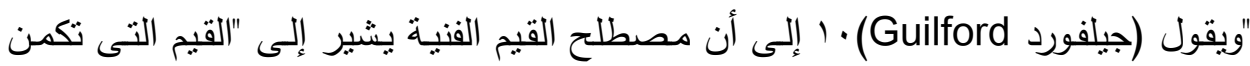

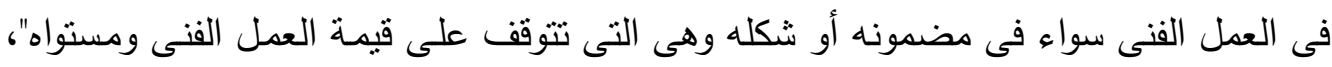

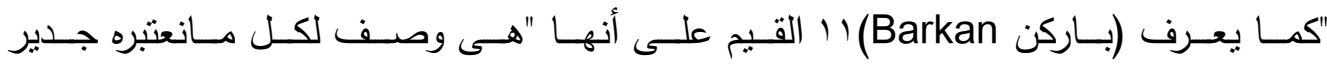

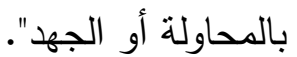

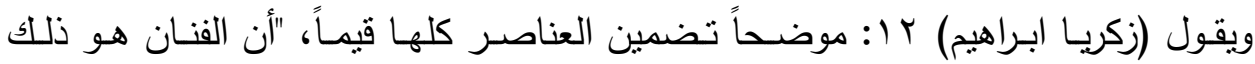

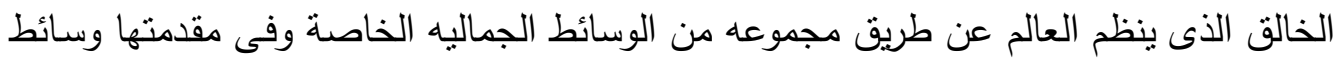

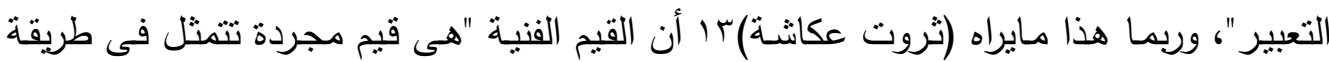

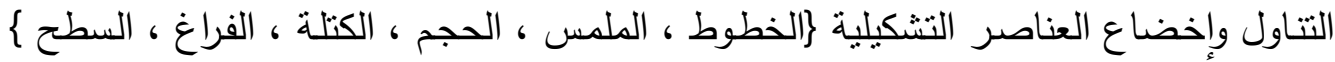
لنسق تتجلى فيه براعة الفنان فى التصوير والإبداع". 
أما (هربرت ريد)" ا ا فيؤكد ذلك بقوله : "إن هناك شيئاً مشتركاً في جميع الأعمال الفنبة يسمى الثكل ، والمقصود بالثكل هنا فى تعبيره هو البيئة الفنية للعمل الفنى والتى يختلف فئنا

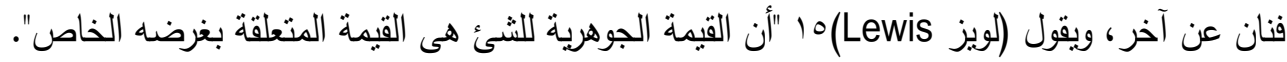

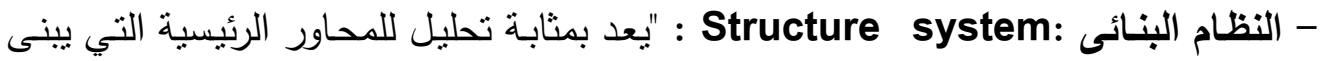

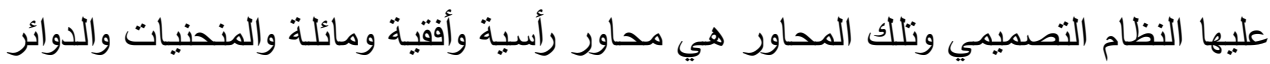

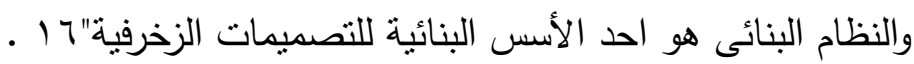

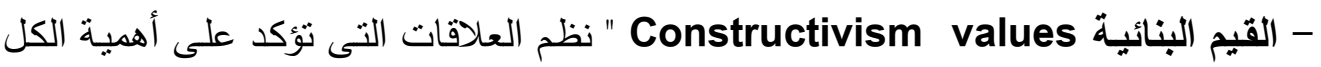

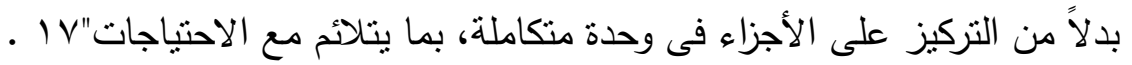

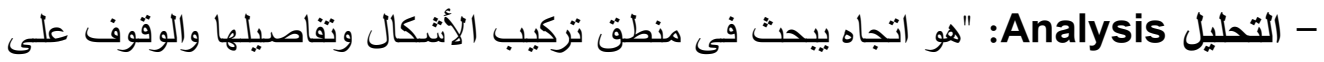

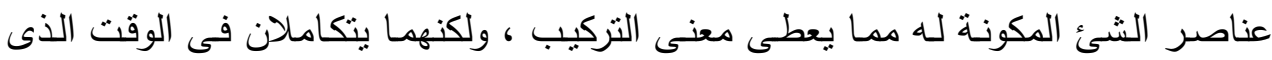

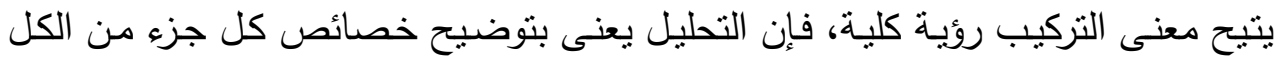
وارتباطه به"(1) 1 ).

التوصيات وإلنتائج توصل الباحث بعد انهاء هذا البحث الى مجموعة من النتائج والتوصيات الهامة والموضحة كما يلى: اولا النتائج: - التراث العمانى مازال قادرا على العطاء الشكلى وتقديم حلول بصرية مميزة يمكن الاعتماد عليها فى استحداث تصميمات جديدة. - النظم البنائية والانشائية لبعض عناصر من التراث العمانى تعتبر حلول مرجعية للاستفادة منها فى البناء التصميمى. - التراث العمانى فى مدلولاته البصرية منأثرا الى حد كبير بالفن الاسـلامى والمنهج الرياضى سواء فى القيم البنائية او الصيغات الثيات فلئية. ثانيا التوصيات:

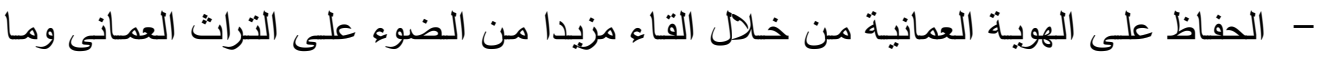

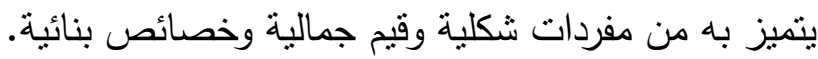

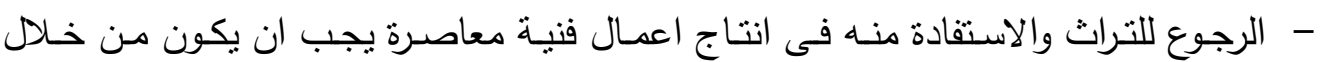
الحفاظ على مضمونه وقيمه وعدم الانخراط فى المعاصرة.

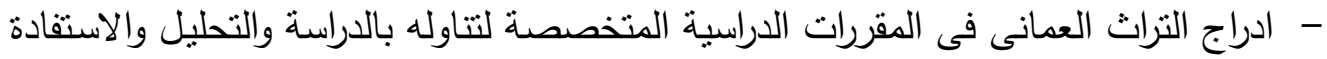

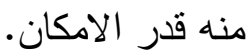




\section{المراجع العربية}

1 - احمد حافظ محمد رشدان (9V^ (م)) "القيم الفنيه فى أعمال محمود مختار والإفادة منها فى إعداد معلم

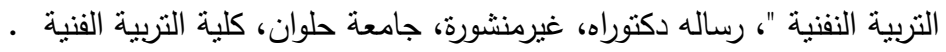

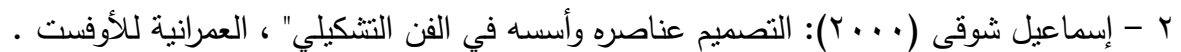

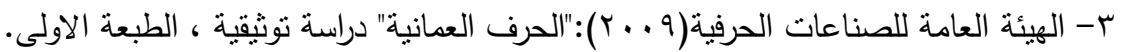

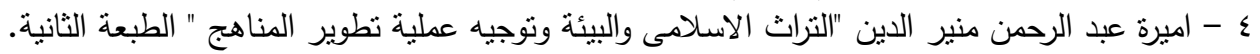

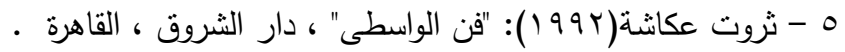

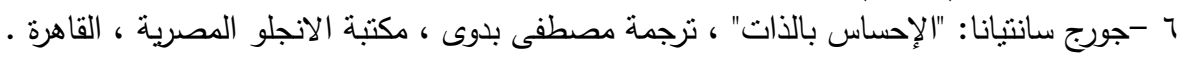

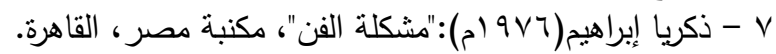

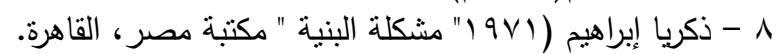

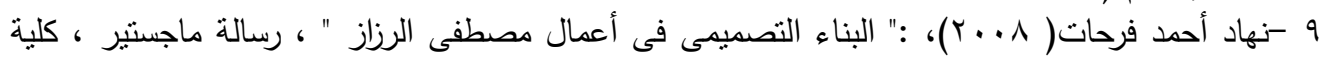

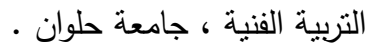

• 1 - هربرت ريد: " التربية عن طريق الفن "، ترجمة عبد العزيز جاد، الهيئة العامة للكتاب والاجهزة العلمية، القاهرة.

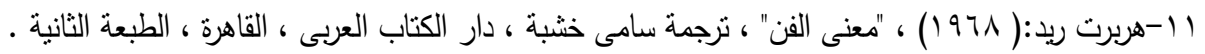

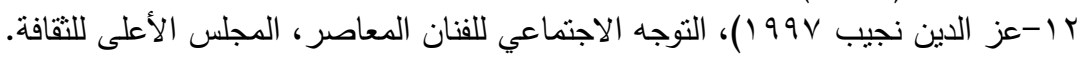

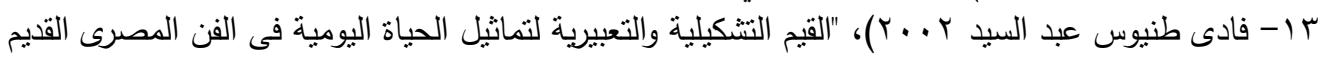

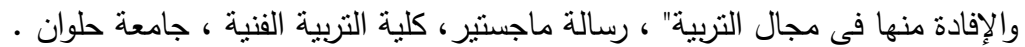

المراجع الاجنبية

1 - Bevlun.M. E :( 1970)"Design Through discovery", Holt Rinehart and Winston,Neues,New York .

2 - C. I. Lewis: (1946), "An Analysis Of Knowledge and Valuation", La Salle, Open Cour.

3 - Guilford: (1979), "Creaive Process', Amontor book.

4 - Manual Barkan: (1955),"A foundation For Art Education", New York, The Ronald Press Company.

5 - The new encyclopedia Britannica: (1985), vol 3, USA.

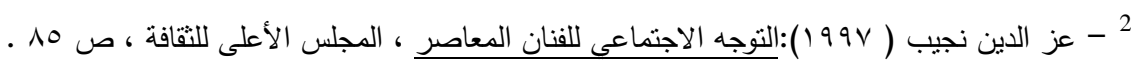

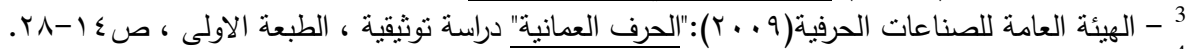

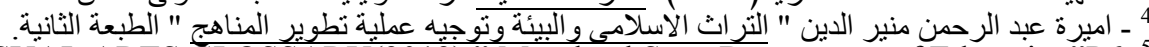

- VISUAL ARTS GLOSSARY(2012):” Maryland State Department of Education"”P6.

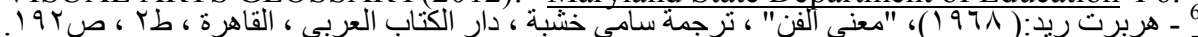

7

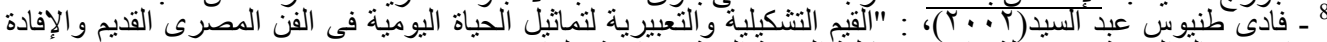

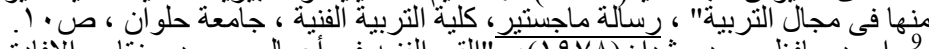

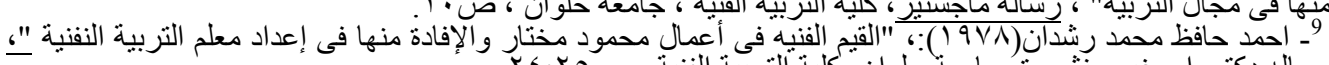

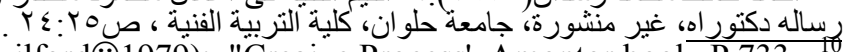

Guilford:01979):, "Creaive Process', Ámontor book, P.733. -

Manual Barkan( 1955):,"A foundation For Art Education", New York, The Ronald Press - 11 Company, P.108.

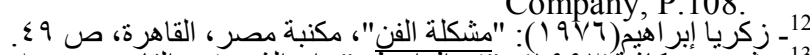

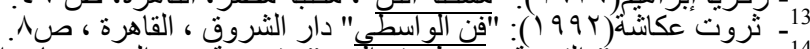

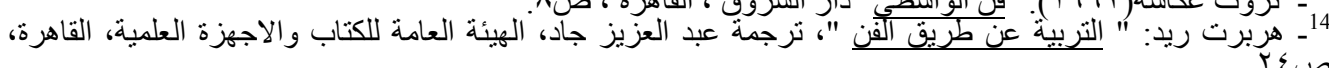

"An Analysis Of Knowledge and Valuation", La Salle, Open Cour, :) 1946( C. I. Lewis - • 15 P.396.

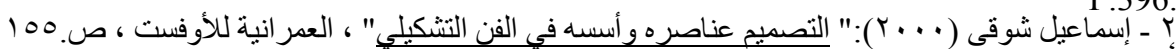
: "Design Through discovery", Holt Rinehart and Winston, Neues, New ) $1970($ - Bevlun.M. E ه جامعة حلو ان ، صند فرحات 